
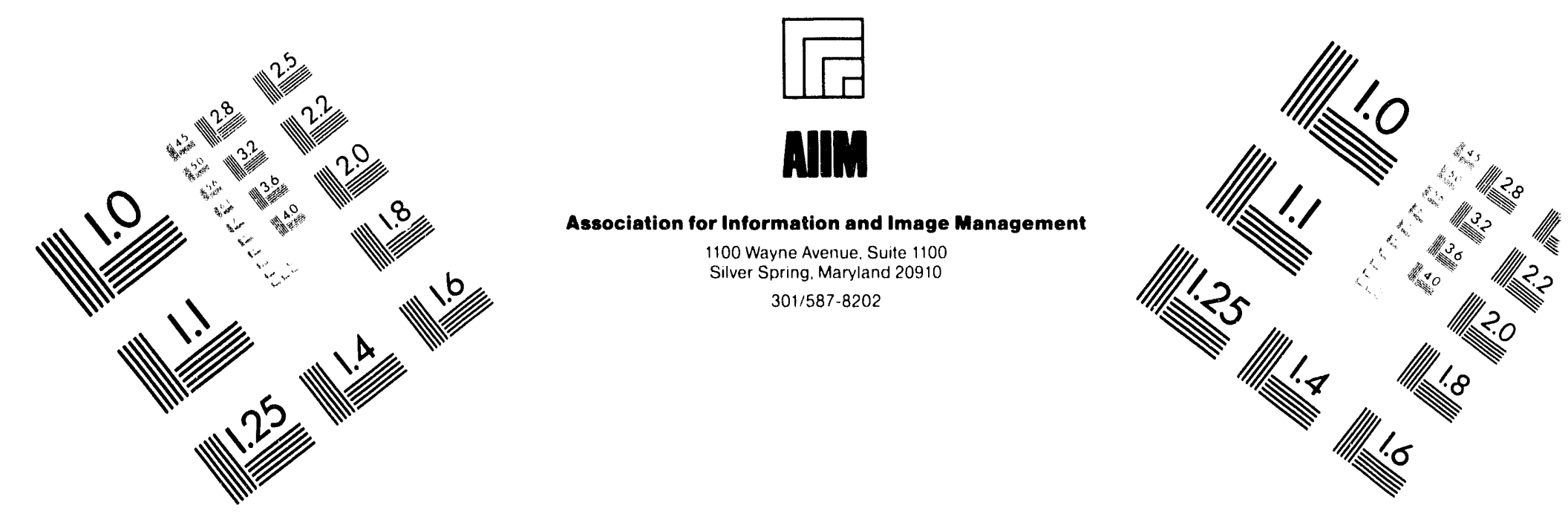

Centimeter

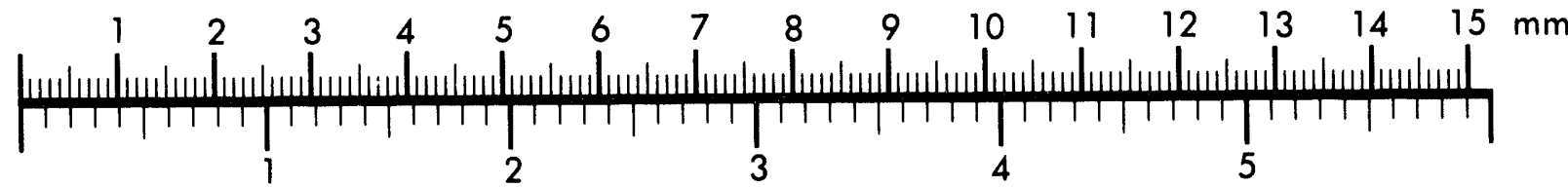

Inches
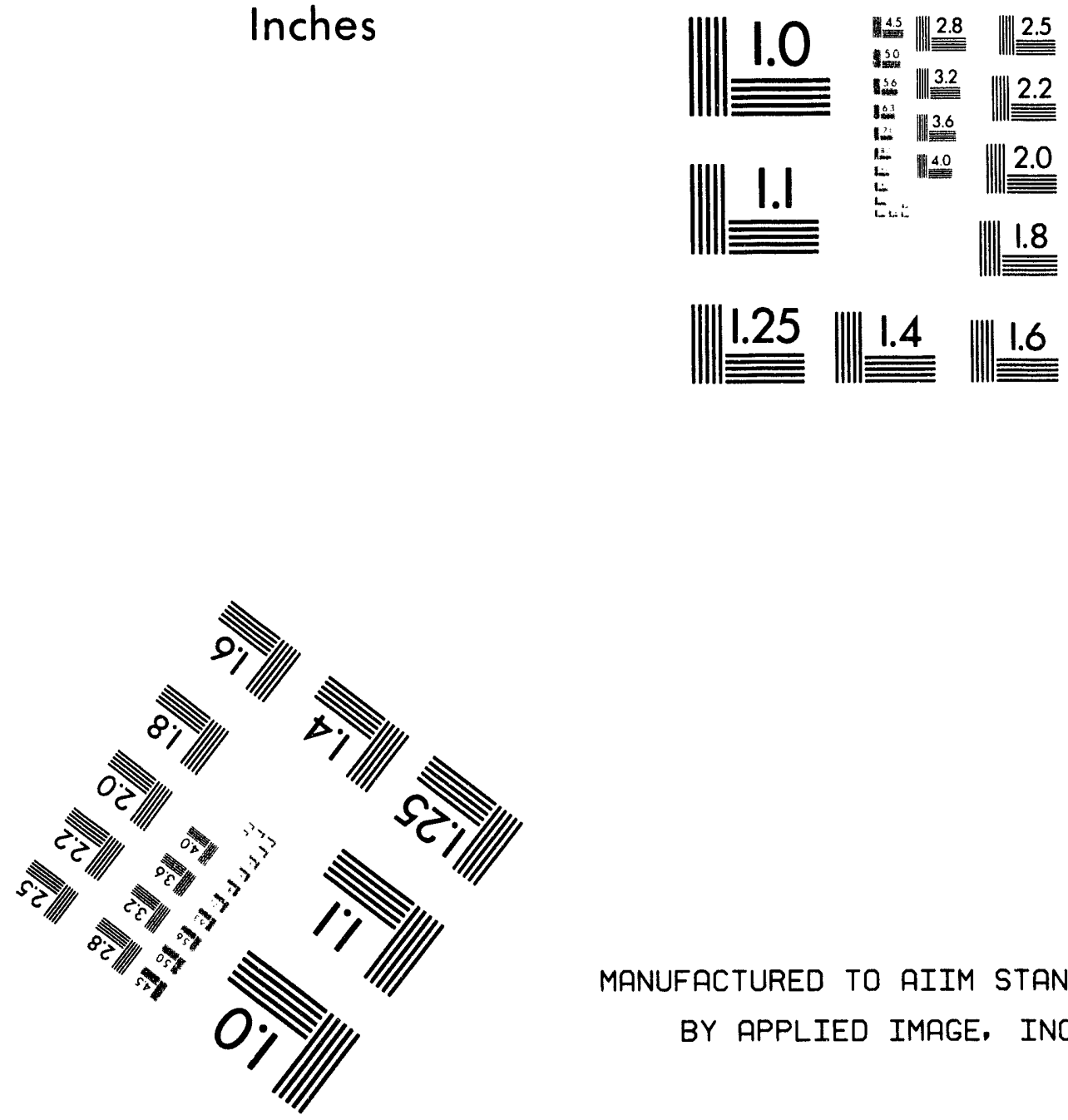

MANUFACTURED TO AIIM STANDARDS

BY APPLIED IMAGE, INC.

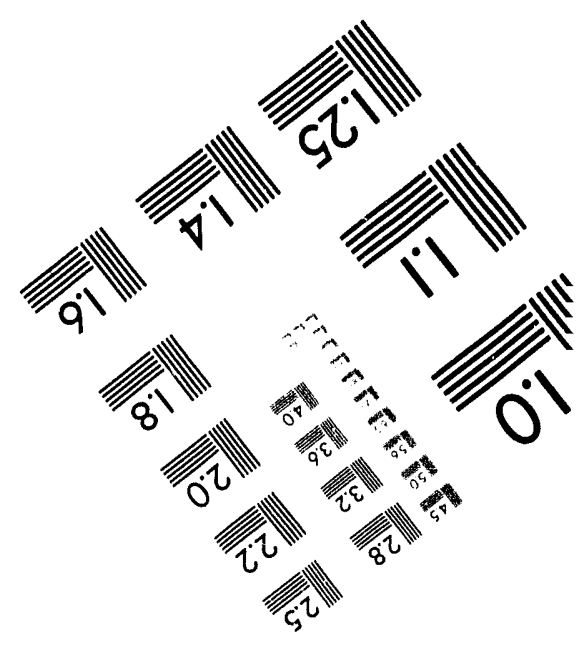



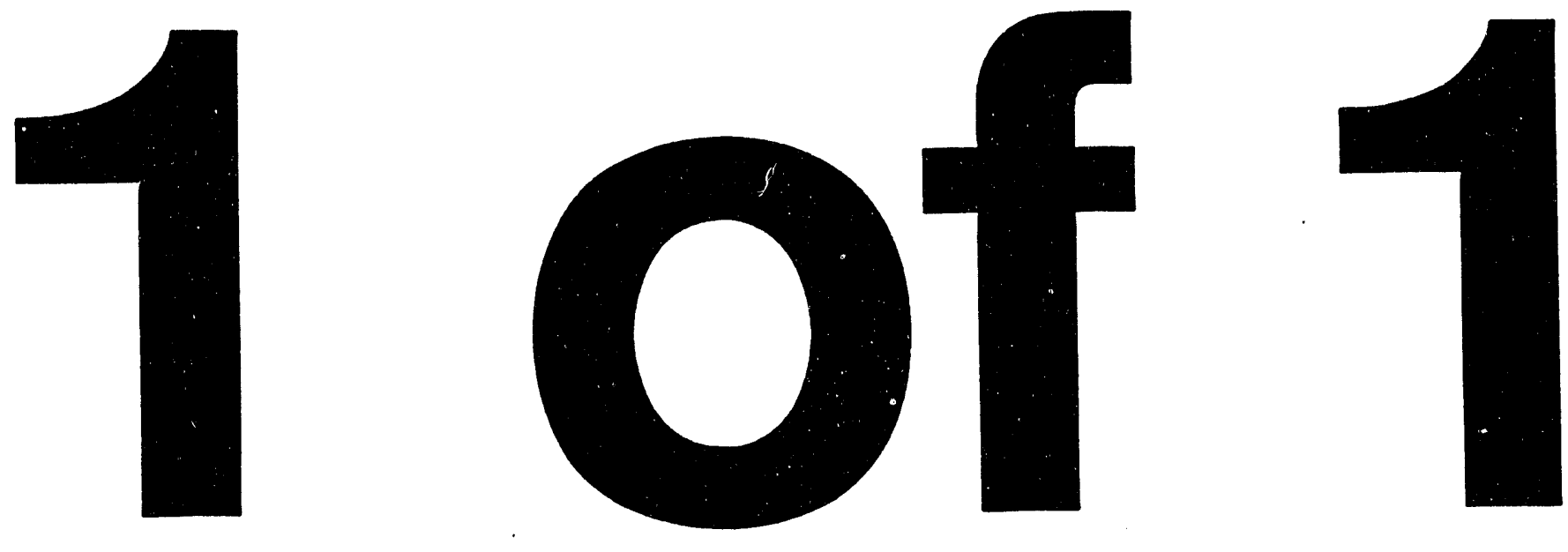


\section{COMBUSTION CHARACTERIZATION}

OF BENEFICIATED COAL-BASED FUELS

QUARTERIY REPORT NO. 12 FOR THE PERIOD JANUARY TO MARCH 1992

PREPARED BY
COMBUSTION ENGINEERING, INC. 1000 PROSPECT HIIL ROAD WINDSOR, CT. 06095

PROJECT MANAGER MICHAEL J HARGROVE

PRINCIPAL INVESTIGATORS OSCAR K. CHOW

N. Y. NSARAIA

AUGUST 1992

PREPARED FOR

U.S. DEPARTMENT OF ENERGY PITTSBURGH ENERGY TECHNOLOGY CENTER UNDER CONTRACT NO. DE-AC 22-89 PC 88654

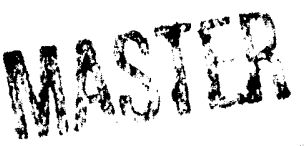




\section{DISCLAIMER}

This report was prepared as an account of work sponsored by the United states Government. Neither the United States nor the United States Department of Energy, nor Combustion Engineering, Inc., nor any of their employees, subcontractors, suppliers, or vendors make any warranty, express or implied, or assumes any legal liability or responsibility for the accuracy, completeness, or usefulness of any information, apparatus, product, or process disclosed, or represents that its use would not infringe privately owned rights. Reference herein to any specific commercial product, process, or service by trade name, mark, manufacturer, or otherwise, does not necessarily constitute or imply its endorsement, recommendation, or favoring by the United states Government or any agency thereof. The views and opinions of authors expressed herein do not necessarily etate or reflect those of the United States Government or any agency thereof. 


\section{INTRODUCTYON}

The Pittsburgh Energy Technology Center of the U.S. Department of Energy has contracted with Combustion Engineering, Inc. (CE) to perform a five-year project on "Combustion Characterization of Beneficiated Coal-Based Fuels." The beneficiated coals are produced by other contractors under the DOE COal Preparation program. Several contractor-developed advanced coal cleaning processes are run at pilot-scale cleaning facilities to produce 20-ton batches of fuels for shipment to $\mathrm{CE}^{\prime} \mathrm{s}$ laboratory in windsor, connecticut. CE then processes the products into either a coal-water fuel (CWF) or a dry microfine pulverized coal (DMPC) form for combustion testing.

The objectiveg of this project include: 1) the development of an engineering data base which will provide detailed information on the properties of BCFs influencing combustion, ash deposition, ash erosion, particulate collection, and emissions; and 2) the application of this technical data base to predict the performance and economic impacts of firing the BCFs in various commercial boiler designs.

The technical approach used to develop the technical data includes: bench-scale fuel property, combustion, and ash deposition tests; pilot-scale combustion and ash effects tests; and full-scale combustion tests. subcontractors to CE to perform parts of the test work are the Massachusetts Institute of Technology (MIT), Physical science, Inc. Technology company (PSIT) and the University of North Dakota Energy and Environmental Research Center (UNDEERC).

Twenty fuels will be characterized during the five-year base program: three feed coals, fifteen BCFs, and two conventionally cleaned coals for full-scale tests. Approximately nine BCFs will be in dry ultra fine coal (DUC) form, and six BCFs will be in coal-water fuel (CWF) form. Additional BCFs would be characterized during optional project supplements. 


\section{SUMMARY}

During the first quarter of 1992, the following technical progress was made.

- Continued analyses of drop tube furnace samples to determine devolatilization kinetics.

- Completed editing of the fifth quarterly report and sent it to the publishing office.

- Prepared two technical papers for conferences. 
Beneficiated coals (BCs) and feed coals are acquired from other DoE projects and shipped to CE. These fuels are then processed into either dry pulverized coal form or coal-water fuel (CWF) form. The feed coals are fired as standard grind (708 minus 200 mesh) pulverized coal (PC), while the dry beneficiated fuels are generally dry microfine pulverized coal (DMPC).

Ten twenty-ton batches of test fuel have been produced under the DOE-PETC COal Preparation program since 1987. These fuels include:
1. Illinois *6 feed coal
2. Pittsburgh $\$ 8$ feed coal
3. Upper Freeport feed coal
4. Illinois *6 microbubble flotation product
5. Pittsburgh $\neq 8$ microbubble flotation product
6. Upper Freeport microbubble flotation product
7. Illinols \#6 spherical oil agglomeration product
8. Pittsburgh $\$ 8$ spherical oil agglomeration product
9. Upper Freeport spherical oil agglomeration product
10. Fresh Upper Freeport feed coal

The first nine fuels were tested in the pilot-gcale facility between october 1989 and June, 1990. Bench-scale testing continued through this quarter. Since the first six fuels had been stored in sealed drums for approximately eighteen months, a fresh 20-ton sample of Upper Freeport parent coal was obtained for testing during october 1992 to evaluate the effects of aging or "weathering". The next BCFs for testing are scheduled to be produced during the second quarter of 1992 . 
TASK 2 - BENCE-SCALE TESTS

All test fuels are fully characterized using various standard and advanced analytical techniques. These tests evaluate the impacts of parent coal properties and beneficiation process on the resulting BCF's qualities.

A few selected fuels are tested in a laminar flow drop tube furnace to determine fly ash particle size and chemical composition. Results include mineral matter measurements and modeling of fly ash history and have been reported in previous quarterly reports and in the paper by Barta, et alia, 1991.

A swirl-stablized, entrained flow reactor is used to characterize the surface compositions and the states of ash particles formed during combustion. Deposition rates on a target are determined, and the size and compositions of the deposits from different fuels are compared. Results were reported in the Quarterly Report for the period January to March, 1991.

The ten coal and BCF samples received to date have been completely analyzed for: (1) complete chemical analyses; (2) flammability index measurements; (3) weak acid leaching; (4) TGA reactivities and BET surface areas of chars, ana (5) combustion kinetics. All these data have been reduced and reported in the Quarterly Reporta for July to September, 1990, January to March 1991, and October to December, 1991, as well as in papers by Nsakala, et alia, 1990 and 1991, and the draft Topical Report issued in June, 1991.

Work during this quarter focused on completing the CE Drop Tube Furnace System-1 (DTFS-1) devolatization testing of the BCFs. The analysis of the samples collected during the tests also continued. 
TASK 3 - PILOT-SCALE TESTING

The pilot-scale studies were designed to provide key information for the technical and economic assessment of the BCFs for commercial applications. Comprehensive tests were conducted in the CE Fireside Performance Test Facility (FPTF) to evaluate the combustion, furnace slagging, convective pass fouling and fly ash erosion characteristics of the BCFs prepared in both dry (micro-fine) and wet (micro-fine coal-water fuel) forms. studies were also carried out to evaluate the effect of BCF fly ashes on electrostatic precipitator (ESP) collection performance. Additionally, representative in-flame solids and ash deposit samples collected were analyzed in detail to enhance the understanding of mineral matter transformation and ash deposition and to relate these to fuel mineral distributions and combustion conditions. Also, complementary experiments were carried out in the MIT Combustion Research Facility (CRF) to provide more detailed information on the combustion and emission characteristics of selected BCFs. These experiments focused on application of the coal-water fuel form.

Ten test fuels were evaluated for combustion and performance testing. These fuels included Illinois No.6, Upper Freeport, Pittaburgh No.8 microbubble flotation products (MFPs), spherical oil agglomeration products (SOAPs), and the MFP parent coals. The pilot-scale results were reported in four previous quarterly reports: May to June, 1990, october to December, 1990, January to March, 1991 and October to November, 1991. Results are also included in the papers by Barta, et alia, 1991, and Chow, et alia, 1991, as well as the draft Topical Report issued in June, 1991.

UNDEERC continued the analyses of the samples taken during testing of two different Upper Freeport parent fuels in the FPTF. The results will be reported in the next quarterly report. 
The purpose of the scale-up tests is to verify that the results obtained from tests done at bench- and pilot-scales in Tasks 2 and 3 can be used to provide reasonable estimates of the performance effectg when firing BCFs in commercialscale bollers. Two beneficiated fuels will be fired in either a small utility boller or a full-acale tegt furnace.

The only activities in this task were discussions on fuel procurement, alternative test facility selection, and scheduling. Recommendations have been submitted to the DOE to run the tests in CE's Boiler simulation Furnace, a $50 \times 10^{6} \mathrm{Btu} / \mathrm{hr}$ unit that models full-scale boilers.

\section{TASK 5 - TECBNICAL-ECONOMIC EVALUATIONS}

The results of bench-scale, pilot-scale, and scale-up tests (Tasks 2, 3, and 4) will be used to predict the performance of three commercial boilers. The boilers include: a 560MW coal-designed utility unit; a 600MW oil-designed utility unit; and an $80,000 \mathrm{lb} / \mathrm{hr}$ oll designed, shop assembled industrial unit. Eight of the base project BCFs will be used in models of each unit to calculate performance.

No activity was scheduled for Task 5 during this quarter.

\section{TASK 6 - TECHNICAL REPORTING}

Final editing of the fifth quarterly report was completed. The final originals were eent to the PETC office of Technology Transfer. A technical paper on the ash deposition results was written and submitted to the coal and slurry Technology Conference to be held in April, 1992.

WORK PLANNED FOR NEXT QUARTER

- Analyze data from bench-scale tests.

- Analyze data from pilot-scale combustion tests and ash deposition tests.

- Procure more BCFs for another series of tests. 


\section{BIBLIOGRAPHY}

Barta, L.E., Togan, M.A., Beer, J.M., Sarofim, A.F. and Hargrove, M.J., "Transformation of Mineral Matter During Combustion of Parent and Beneficiated Upper Freeport Coal," 16th International Conference on Coal \& slurry Technologies, Clearwater, Florida, April 22-25, 1991.

Barta, L.E., G. Vámos, M.A. Toqan, J.D. Teare, J.M. Beér and A.F. Sarofim; "A Statistical Invegtigation on Particle to Particle Variation of Fly ash Using SEMAIA-EDAX Technique". Material Research Society, 1989. Fall Meeting, Boston, Paper W1.6.

Barta, L.E., Horváth, F., Beér, M.J., Sarofim, F.A.: Mineral Matter Distribution in Individual Pulverized Coal Particles; Application of the "URN" model. Presented at the "Twenty-third International symposium on Combustion". Orléan, France July 22-27, 1990.

Barta, L.E. and J.M. Beér; "Distribution Functions of Chemical Compounds and Viscosity of Fly Ash Originated from Monosize Coal Particles in the Case of Total Mineral Coalescence", Internal Report, MIT Cambridge, MA, June, 1990.

Beer, J.M., Proc. Anthracite Conference, Bull. 75, Mineral Industries Experiment station, The Pennsylvania State Univergity, September, 1961.

Chow, O.K., Hargrove, M.J., and Levasseur, A.A., "The Impact of Beneficiated Coal-Based Fuels on Boiler Performance," 16th International Conference on Coal \& Slurry Technologies, Clearwater, Florida, April 22-25, 1991.

Chow, O.K., Lexa, G.F., Levasseur, A.A. and Mehta, A.K. "Combustion Characterization of the Kentucky No. 9 Cleaned Coals," EPRI Final Report CS-4994, February 1987 .

Durant, J.F., Kwasnik, A.F., Levasseur, A.A. and Baumann, P.D., "Impacts of Cleaning Texas Lignite on Boiler Performance and Economics," EPRI Final Report GS-6517, August 1989. 
Feeley, III, T.J., and Hervol, J.D., "Testing of Advanced Physical Coal Cleaning Processes--Current status," presented at Fourth Annual Pittsburgh Coal Conference, Pittsburgh, Fennsylvania, September 28-october 2, 1987.

Field, M.A., Gill, D.W., Morgan, B.B., and Hawksley, P.G.W., "The Surface Reaction Rate of Carbon with Oxygen," Combustion of Pulverised Coal, BCURA, Leatherhead, England, 1967, p. 329.

Goetz, G.J., Nsakala, N., and Patel, R.L., "Combustion and Gasification Kinetics of Chars from four Commercially significant Coals of Varying Rank," Proc. International Conference on Coal Science, 1983, p. 571.

Griffith, B.F., Lexa, G.F., Teigen, B.C., Levasseur, A.A. and Mehta, A.K., "Pilot-Scale Combustion Characterization of Two Illinois Coals," EPRI Final Report CS-6009, November 1988.

Hargrove, M.J., et al., "Commercial Applications and Economics of Coal-Water Fuels," Final Report Volume 6, DOE Contract DE-AC-22-82 PC 50271, November, 1989.

Huettenhain, H. and Schaal, A.M., "Advanced Physical Fine Coal Cleaning by Spherical Agglomeration, "Final Report for U.S. DOE/PETC under Contract DE-AC-2287 PC 79867, September 1990.

Huffman, G.P., Huggins, F.E., Dunmyre, G.R., Pignocco, A.J. and Lin, M.C., "Comparative Sensitivity of Various Analytical Techniques to the Low-Temperature Oxidation of Coal," Fuel, 64, 849(1985).

Mitchell, R.E., "Experimentally Determined Overall Burning Rates of Coal Chars," Combustion Science and Technology, 53, 165 (1987).

Neakala, N., Goetz, G.J., Patel, R.L., Lao, T.C., Hickerson, J.D., and Ritz, H.J., "Pyrolysis and Combustion Characterization of Pulverized Coals for Indugtrial Applications," 189th ACS National Meeting, Miami, Florida, April 28May 3, 1985. CE Publication TIS -7877. 
Naakala, N., Patel, R.L. and Borio, R.W., "An Advanced Methodology for Prediction of Carbon Loss in Commercial Pulverized Coal-Fired Boilers," 1986 JPGC, Portland, Oregon, October 19-23, 1986. CE Publication TIS-8211.

Noakala, N. Patel, R. L., and Hargrove, M. J., "Physical, Chemical, and Reactivity Characteristics of Beneficiated Coal-Based Fuels," 15th International Conference on Coal and Slurry Technologies, Clearwater, Florida, April 23-26, 1990.

Naakala, N. Patel, R. L., Raymond, D. R., Hargrove, M. J., Hurley, J. P., and Benson, S. A., "Effects of Coal Natures and cleaning Processes on the Physiochemical and Reactivity Characteristics of Beneficiated Coal-Based Products," 16th International Conference on Coal and slurry Trchnologies, Clearwater, Florida, April 22-25, 1991.

Raask, E.; Mineral Impurities in Coal Combustion: Behavior, Problems, and Remedial Measures. Hemispheres Publishing Corporation, Washington DC, 1985.

Sarofim, A.D., J.B. Howard, and P.S. Padia, "The physical transformation of mineral matter in pulverized coal under simulated combustion conditions," Combustion science and Technology, 16, 187-204 (1977).

Schaal, A.M., and Lippsmeyer, B.C., Proof-of-Concept Results Using the Arcanum/Bechtel spherical Agglomeration Approach to Clean Ultra-fine Coals," EPRI's 15th Annual Fuel science Conference, Palo Alto, California, June 19-21, 1990 .

Smouse, S.M., McIlvried, T.S. and Avon, B.M., "Characterization of Advanced Physical Coal-Cleaning Products," 15th International Conference on Coal \& slurry Technologies, Clearwater, Florida, April 24-27, 1989.

straszheim, W.E., "Application of automated image analysis to the study of mineral matter in raw and processed coals," Ph.D. Thesis, Iowa State University (1986). 
Walker, Jr.,P.L., Rusinko, Jr., F., and Austin, L.G., "Gas Reactions of Carbon," Advances in Catalysis, Vol 11, Academic Press, N.Y. and London, 1959, p. 133.

Watt, J.D. and F. Fereday; "The Flow Properties of Slags Formed from the Ashes of British Coals: Part 1. Viscosity of Homogeneous Liquid slags in Relation to slag Composition". Journal of the Institute cif Fuel. March 1969. 

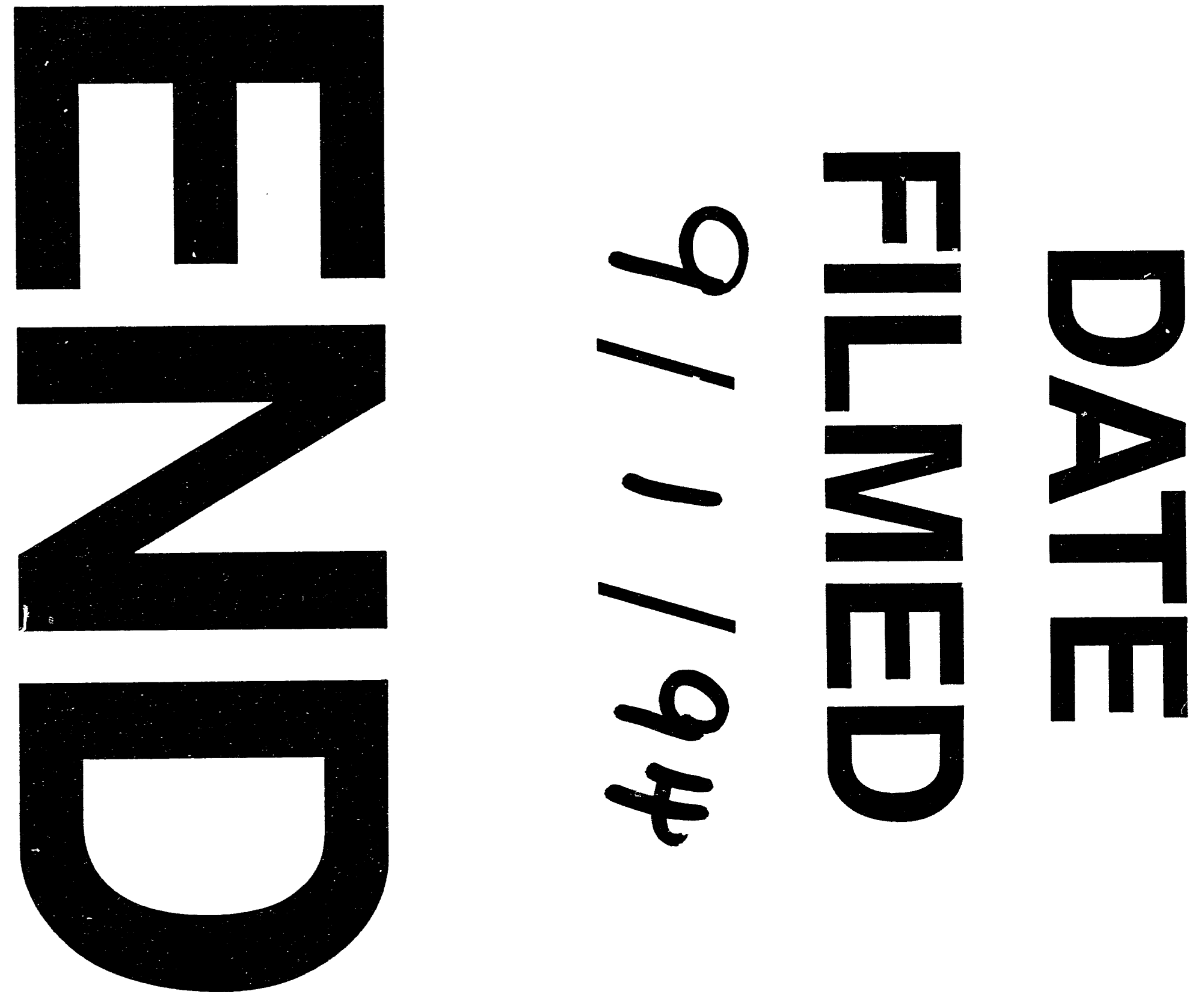


$$
\longrightarrow
$$

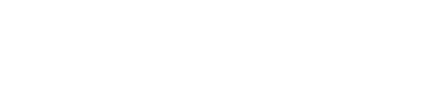
..... | 